Africa Development, Vol. XXIX, No. 4, 2004, pp. 1-18

(C) Council for the Development of Social Science Research in Africa, 2004

(ISSN 0850-3907)

\title{
The Alternative Genealogy of Civil Society and Its Implications for Africa: Notes for Further Research ${ }^{1}$
}

\author{
Ebenezer Obadare*
}

\begin{abstract}
Despite its ubiquity in popular and academic discourses, consensus about the epistemological status of the idea of civil society remains elusive. In Africa, the literature is circumscribed by doubts about, first, its applicability; and second, the usefulness of civil society in explicating social processes on the continent. This has generated a conflictive, yet deeply illuminating, scholarship. The paper makes a modest contribution to the debate, first, by mapping the main contours of the existing intellectual divide, and second, critically complicating it by suggesting the emergence of an 'alternative genealogy' that seemingly renders the debate itself redundant. The 'alternative genealogy' seems to have emerged, partly out of the desire to respond to misgivings about the possibility of civil society in Africa, and partly to provide a description of civil society which, while not totally divorced from its original meaning(s), nevertheless strikes out in fresh directions, taking into cognisance the radical ways in which the notion of civil society is being used across non-Western societies in general. The paper concludes with an examination of the implications of this re-imagining of civil society for both theoretical analysis and practical engagement.
\end{abstract}

\section{Résumé}

Malgré son omniprésence dans les discours populaires et académiques, il n'y a toujours pas de consensus bien défini autour du statut épistémologique de la notion de société civile. En Afrique, la littérature est circonscrite par des doutes relatifs à l'applicabilité de cette idée, et à l'utilité de la société civile en matière d'explication des processus sociaux en cours au niveau du continent. Ceci a généré un débat académique à la fois conflictuel et assez éclairant. Cette

* Ford Foundation International (PhD) Fellow and Lord Dahrendorf Scholar, Centre for Civil Society, Department of Social Policy, London School of Economics and Political Science, London WC2A 2AE. E-mail: e.Obadare@Ise.ac.uk or omowura2000@yahoo.com 
présentation apporte une modeste contribution à ce débat, tout d'abord en traçant les principaux contours de la division intellectuelle existante, puis en exacerbant celle-ci de manière critique en suggérant l'émergence d'une 'généalogie alternative' qui rend le dẻbat superflu. La 'généalogie alternative' semble être née de la volonté de réagir aux doutes relatifs à la possibilité d'instauration d'une société civile en Afrique; elle découle également, en partie, de la volonté de fournir une description de la société civile qui, tout en ne se départant pas totalement de sa (ses) signification originale(s), n'en adopte pas moins de nouvelles orientations, en tenant compte de l'utilisation radicale de la notion de société civile dans les societés non occidentales, en général. L'auteur conclut par une étude des implications de cette redéfinition de la société civile, au niveau de l'analyse théorique et de l'engagement pratique.

It is in the nature of the problem that the debates about civil society remain inconclusive; but these are not, for that reason, fruitless. After all, these debates form parts of a collective reflection on the nature of the conditions which political democracy requires to take root and flourish. Precisely because of its elusiveness and intractability the idea of civil society in the Third World forces us to think about the social terrain behind the explicit political institutions and to try to explicate what happens in that essential but relatively dark analytical space (Sudipta Kaviraj 2001:323).

\section{In lieu of an introduction}

Sometime in late 1993, while reporting underground for TEMPO, Nigeria's frontline opposition newspaper, I was puzzled by a question put to me by a correspondent of a foreign journal who interviewed me for a story on the activities of what at that time was easily the only audible voice in a gagged Fourth Estate. Having cross-examined me about my motivation for working for a guerrilla publication under such personally perilous circumstances, and having in turn promptly obliged with the right noises about 'justice' and 'equality', he went on to ask me if I had considered the likely implications of the press's exemplary doughtiness for 'civil society' at large. This was my first acquaintance with 'civil society', an article that was just about then making its way into the terminological market, before it became insinuated into the everyday vocabulary of anti-authoritarian and pro-democracy forces in Nigeria, and nay Africa at large. I cannot immediately recall the response I gave to my eager interrogator; but I remember making a mental note to check up on the actual meaning of the strange animal. Suffice to add that since that time, civil society has witnessed a general explosion in its usage to become what John and Jean Comaroff (1999) call the idée fixe of the contemporary era, courted by sundry groups to champion, justify or promote various social and political projects. 
I have followed on this personal trail to illustrate two points. The first is the by now well-known fact that civil society as an analytic concept did not acquire its contemporary currency in most parts of the African continent, certainly not in Nigeria, until the closing years of the 1980s, after which it then became arguably the epicentre of a major intellectual ferment. Nwokedi rightly observes that 'up until the widespread demand for political reform... beginning in the late $1980 \mathrm{~s}$, the use of civil society as an analytic variable in the study of sub-Saharan politics was an exception rather than the rule' (Nwokedi 1995:63). A number of factors have been implicated in this process of altogether sudden conceptual fame of the notion of civil society, but it is generally agreed that the most critical singular factor, if any, was the momentous events associated with the collapse of the socialist experiment in the former Soviet Union and the attendant unpopularity of Soviet-like social systems in different parts of the globe. Some would argue, with some merit, that we have yet to see the back of the myriad consequences unleashed by that fateful collapse.

In truth, even before the Soviet Union expired, a popular surge in favour of increased liberalisation of the political space had been evident on the African landscape. To take one example: in 1979, a whole decade before the Gorbachev projects of perestroika and glasnost came to grief, a combination of persistent pressure from 'civil society' and a measure of consensus within the highest echelons of the Nigerian military had led to the voluntary transfer of power by the Obasanjo regime to the elected civilian government of Shehu Shagari. This fact becomes more remarkable when it is recalled that the subsequent epidemic of 'democratic' 'transitions' (Diouf 1998) to civil rule across the continent was still, at that time, little more than a forlorn hope. Once the Wall gave way (and the Soviet state 'withered away') however, the dream of social pluralism became more or less instantly realistic. The symbolism of the collapse of the Berlin Wall was not lost on popular forces throughout the continent, and it opened a dam of agitation that has left deep furrows everywhere on the continental landscape. While it may be true that basic ethnographic particulars mainly shaped the nature of oppositional politics that challenged ossified regimes everywhere on the continent, what is virtually beyond any shade of doubt is the fact that in general, the various pro-democracy forces had been massively impressed by the emergent global clamour for a 'civil society'. Howell and Pearce describe this inspirational quality of civil society thus:

Much of the challenge, particularly in the South and Eastern Europe, came from peoples: workers, intellectuals, clergy, poor women, and young people, who rejected the cruelty and corruption of their governments... 'civil society' was reinvented as a conceptual weapon in this challenge. Initially it represented a claim to the right of self-determination in societies where the totalitarian state denied the very principle (2001:15). 
This insight is similarly applicable to the processes of 'democratisation' (yet another conceptual offspring of that heady era) in contexts as varied and apart as Zambia, Togo, Nigeria, Ghana, Gabon, Republic of Benin, and Cameroon (Ihonvbere and Shaw 1998). ${ }^{2}$ Civil society became a notional rallying point, an ideological shelter where ordinarily polarised forces pooled their antipathy (momentarily at least) towards the authoritarian African state. ${ }^{3}$ This invocation of civil society plugged into a similar awakening in other parts of the world where the idea had come to embody layers of historical meanings. With specific reference to Eastern Europe, Chandhoke has identified three of such meanings. First, the civil society argument sought to limit formerly untrammeled power of the state by the institutionalisation of political, but more importantly, civil rights and the rule of law. Second, and correspondingly, the argument sought to carve out a domain that would function independently of state regulation. Here people, free from state inspired diktat, could engage in projects of all kinds. Third, the civil society argument propelled an important issue onto the political agenda. It simply asserted that the active engagement of ordinary men and women in groups that were smaller than the state, namely family and kinship groups, neighbourhoods, professional and social associations, and voluntary agencies, was a good thing in itself (Chandhoke 2001:2).

A second point that I would like to underscore relates to the epistemological status of civil society as an idea. From the personal anecdote that I briefly recapture above, it would appear that civil society, especially when narrowly defined in relation to certain specific practices, might not be as alien to the African landscape as a section of the theoretical literature on the subject definitely makes it out to be. When the journalist asked me how I felt about contributing to the strengthening of civil society, he apparently took it for granted that there already was a civil society, or at least something approximating to one. ${ }^{4}$ More important however, is the light this helps to cast on the crucial distinction between civil society as an idea, and as an existent and functioning reality, a distinction usually glossed over in many studies.

This latter problem is critical because it goes to the heart of the existing debate about the nature and possibilities/limitations of civil society in Africa. This paper makes a modest contribution to this debate, first, by highlighting its main contours in terms of the existing scholarly divide, and second, by critically complicating it by suggesting the emergence of an 'alternative genealogy' (Howell and Pearce 2001) that seemingly renders the debate itself redundant. In order to put these contributions in their proper perspective, I will proceed by summarising the general background to the debate on the nature of civil society in Africa. 


\section{An African civil society?}

Civil society...reflects not only a particular stage of historical development in the West but the particular conditions that obtained there and not necessarily in other parts of the world (Gellner 1994:169).

The academic discourse on civil society in Africa might be still growing, but it has nonetheless continued to be haunted by persistent doubts regarding the nativity of the concept, and thus its applicability or otherwise to African social and political circumstances. There is a rough divide between sceptics who doubt the usefulness of civil society in explicating African (nay, nonWestern) realities (Hutchful 1994; Callaghy 1994) ${ }^{5}$ and relative enthusiasts who see it as a useful tool of analysis, if not of praxis (Lewis 2002; Chan 2002). Occupying the cleavage in between are a good number of scholars who, while admitting the relative merits of the two perspectives, nevertheless advocate caution in the way civil society is used (Chandhoke 2001; Trentmann 1999). What is less obvious perhaps is the larger theoretical controversy into which the divide in question is folded, and of which it is a mere fallout, and it may be appropriate here to reflect briefly on this for the sake of perspective and clarity.

Inevitably, the question of the provenance of civil society has been bound up with the similarly unsettled matter of its definition. In discussing the origins of civil society, scholars invariably have to come to terms with what it means. Thus, it may be impossible to uncouple the meaning from the provenance, especially if one were to appraise civil society from the point of view of its classical Western emanation.

In any case, some scholars argue that this is the only valid and noncontradictory way of conducting any such appraisal (Nairn 1997). 'Civil society', Serif Mardin affirms, 'is a Western dream, a historical aspiration'. Mardin echoes a tradition that traces its genealogy back to Hegel, Adam Ferguson, the Scottish Enlightenment thinker, and, in more recent times, to Ernest Gellner and Adam Seligman. The basic arguments of this school, ${ }^{6}$ what elsewhere I have called the 'civil society-as-Atlantic society' school, can be summarised as follows.

First, it is held that civil society, being an outcome of specific processes in the West, is irreproducible outside that self-same geo-political ambiance. The unique history that this Western exceptionalism alludes to is real. ${ }^{7} \mathrm{We}$ can break it down as follows. According to Adam Seligman, the idea of civil society emerged in late seventeenth century and eighteenth century Europe as a result of 'a crisis in social order and a breakdown of existing paradigms of the idea of order' (Seligman 2002:14). He goes on to specify the character of this emergent crisis as follows: 'Whereas traditionally the foundations or 
matrix of social order was seen to reside in some entity external to the social world - God, King, or even the givenness of traditional norms and behavior itself - these principles of order became increasingly questioned by the end of the 17th century' (Ibid). Admittedly therefore, civil society was, ab initio, a normative prototype impelled by the felt need to tame the demon of unfeeling individuation unleashed by the forces of rapid industrialisation. The accent on rationality as opposed to feelings that was the immediate by-product of the European Enlightenment, and the emergence of the market as the arena where the new individual could realise his new found 'freedom' had to be tamed by something much larger than the private individual himself, hence 'civil' society'. It was a society, as Tester (1992) said, of 'less barbarous manners'. Note the paradox, then: While 'the developing economy of market relations in the 18th century problematized social existence in new ways', (Seligman 2002:16) creating among other things, the highly autonomous social actor, it also unwittingly invoked 'a greater stress on community, on the "reestablishment" of some public (and perforce communal) space to mediate somewhat what are seen as the adverse effects of the ideology of individualism' ${ }^{8}$ (Seligman 2002:28).

We round off this point with two clear insights, first of the reality of civil society as a unique emanation from a specific conjuncture in Western social and cultural history, and second, as something imagined, a normative understanding of "what ought to be the relationship among the individual, the society and the state' (Howell and Pearce 2001:13).

A second argument, in some ways an extension of the first, is to view civil society as connoting the possession of certain values (for example privacy, individualism and the market) which are present in and actually define the West but are, alas, absent in non-Western contexts. In this light, civil society becomes what the West has but 'others' don't, others in this context ranging from other cultures to other socio-political systems, or at times a combination of both. Within this understanding, Jack Goody notes, civil society becomes 'like human rights... what authoritarian regimes lack by definition. It is what the Greeks, the Enlightenment and we today have; it is what despotic governments, whether in the past or the present, the here or the elsewhere, do not have' (Goody 2002:150). It is also, above all, an understanding that confirms Kaviraj's (2001) wry observation that from time to time (or for some time), civil society appears to have been used to 'denigrate the other'.

A third complementary understanding of civil society from within this western-centric paradigm is its conceptualisation as the highest (and qualitatively the purest) in the hierarchy of types of society achieved by different cultural communities. According to this notion, the idea of civil 
society could be used to separate (non-Western) societies that are rooted in monarchism and absolutism from those (obviously Western) in which there is a 'regulatory framework accepted by all' (Howell and Pearce 2001:21). The former, seemingly, is the domain of the uncivil, and the latter the civil.

Several critical issues are thrown up by these three modes of understanding. I will address just two. The first is the subtle transformation of the major issue(s) in the critical discourse of the idea of civil society from 'what' it means to the altogether more political issue of 'who' owns it. While it is beyond any argument that civil society is a child of Western political history, it is doubtful whether those who stridently affirm this specificity do not have a different agenda altogether in mind. It is one thing of course to argue that civil society's original spoors can be traced back to the West, but a different matter entirely to use the same fact as a marker between supposedly superior and inferior cultures. For instance, there seems to be more than sheer factual accuracy in Gellner's celebration of civil society as a 'social form among others', ${ }^{9}$ one unlikely to be had by 'segmentary non-Western societies ...pervaded by awesome ritual' (p. 103) or for that matter 'ritual-pervaded cousingly republics, not to mention, of course, outright dictatorships or patrimonial societies' (p. 43). A similar affirmation of cultural exceptionalism is found in other thinkers, including Ferguson and, especially, Hegel, for whom civil society is, among other things, 'the achievement of the modern world...' ${ }^{10}$. This 'culturalisation' has triggered a multitude of reactions, most especially in other parts of the world where scholars have taken it upon themselves to debate the applicability or otherwise of civil society to their respective socio-cultural contexts. In the specific context of Africa, I have already indicated the existence of two divergent and apparently irreconcilable discursive traditions.

In the second instance, a summary of the three different conceptions outlined above would seem to suggest that, specific nuances apart, they all appear to converge on the imagination of civil society as an idea that ultimately expresses what Howell and Pearce describe as '... the rupture of a society rooted in blood and kinship ties to one whose development rests on the individual freed from such ties...' (2001:19). Clearly, this assumption has obvious implications for African societies, generally believed to be steeped in communal logics. Given this seemingly fundamental epistemological barrier then, how is civil society to be imagined on the continent?

\section{Civil society in Africa: A summary of the main perspectives}

Far from being a comprehensive analysis of the extensive literature on civil society in Africa, ${ }^{11}$ what follows in this section is an attempt at a somewhat arbitrary taxonomy, the aim being to highlight the broad areas of convergence 
and divergence among scholars. In this regard, perhaps it might be appropriate to begin with Peter Ekeh's sagely warning of the danger of '... misapplying Western political constructs to African circumstances, especially when their analyses concern such history-soaked concepts as civil society' (Ekeh 1992:188). This warning would seem to be the benchmark for scepticism about the usefulness of civil society for explicating African, nay non-Western realities. In broad terms, Ekeh's scepticism is shared by, among others, Hutchful (1991), Mamdani (1997), Gyimah-Boadi (1997), (Mustapha 1998) and Africanists such as Orvis (2001) and Callaghy (1994); and Chandhoke (2001) and Darnolf (1997).

We should state straightaway that these scholars have been grouped together for the sake of analytic convenience, for in truth, there exist several subtle differences in their opinions. What would seem to unite them is the element of doubt, particularly at what Callaghy, in an objection that recalls Ekeh, articulates as the impropriety of using a 'vague, often confusing and ever shifting concept', one with 'all its attendant historically specific baggage', to analyse African social systems. While the first part of the complaint about civil society being ambiguous and imprecise may come across as familiar, it is the latter rejection based on the presumed foreignness of the idea that appears to cut across the sceptics' ranks. Perhaps there is a need to state more clearly the fundaments of this rejection.

It is true that in seeming defiance of Ekeh's cautionary note, civil society has been liberally used to describe and analyse a variety of situations and promote sundry intellectual and political projects. As I already explained above, this 'democratisation' is partly explicable by the circumstances surrounding the latest emergence of the idea and its perceived appropriateness for the enunciation of a pluralist agenda in confronting entrenched dictatorships throughout the African continent. Admittedly however, this 'promiscuous' (Deakin 2001) embrace has had its own untold consequences, one of which is the obvious lack of attention to the historical and cultural particulars which the Ekeh school believes is so fundamental. Blaney and Pasha (1993) arguably had a similar menace in mind when they also lamented the perceived failure of Third World conceptualisations of civil society in general to take into account 'matters of structure and process' - another oblique reflection of the seeming uneasiness with the geo-cultural ancestry of the idea.

While uneasiness at the alien nativity of civil society may be one source of scepticism, there are, in general, those who have even deeper problems with the allied issue of its unresolved 'ontological status' (Comaroff and Comaroff 1999). This is a more direct reference to the miasma of imprecision that has always surrounded civil society, even within the western universe of its origins. ${ }^{12}$ The argument would seem to be: If civil society cannot be held 
down to a particular definition, or even a set of meanings, how useful can it be in explaining dynamic social processes? Callaghy for example doubts 'whether civil society as commonly defined can do much to elucidate important processes in contemporary Africa, can do more than label them vaguely, can be more than a "metaphor masquerading as a player" (1994:235). He continues: "The current search for "civil society" is much like the long Africanist flirtation with class analysis; you often "find" what you go looking for if you just try hard enough. In the case of civil society, I would argue that there is even less reality out there than with "classes"' (1994:250). In a similar vein, Hutchful warns that:

As a historical moment... the notion (civil society) is associated with fundamental transformations in western society and economy that do not necessarily apply to the African condition (capitalist modernisation, urbanisation, the communications revolution and growth of literacy, the dissolution of traditional bonds and the decline of religious consciousness (Quoted in Van Rooy 1998:22).

By contrast, he concludes, "African "associational life" is most often made up of ascriptive groupings (organisations one is born into) rather than voluntary ones, and ones that may be entwined with the State and ravaged by outside forces (ethnicity, sectarianism, etc)' (Quoted in Van Rooy 1998:22).

Two interrelated issues emerge here. The first is the rejection of civil society based on its valid appreciation as a foreign concept. The second issue, one that has been further explored in the more recent African discourses of civil society, is the rejection of civil society because of its presumed incompatibility with some basic elements of the African socio-cultural make-up. This problem is what Hutchful's allusion above to Africa's plethora of ascriptive groupings aims to capture. This position is also quite significant, especially as it recalls the arguments of the 'civil society-as-Atlantic society' school that I referred to earlier. Be that as it may, it does raise certain pertinent questions about the nature of civil society in Africa, or even in non-Western contexts in general. For example, does the presence of ascriptive groupings necessarily militate against or make civil society impossible; what are the implications of Hutchful's 'outside forces', ethnicity and sectarianism, ${ }^{13}$ for civil society; is Africa really as culturally exceptional as this reasoning would partly suggest?

The intention, of course, is not to attempt to answer these questions here, apart from noting that they have formed part of a larger debate in the theoretical literature on the relationship between kinship, ethnicity and civil society (Barber 2001; Varshney 2001).${ }^{14} 1$ have only dwelled on them so as to give a sense of the reasoning behind the position of those who, in the broadest terms, doubt the applicability civil society to African social and political 
processes, and the possible theoretical implications of some of the bases of their scepticism. The argument of this school, especially the part of it relating to kinship, seems to have been summed up by Ekeh (1998) thus:

The... problem confronting the successful adoption of the elements of civil society in Africa concerns the relationships between individuals and kinship... Kinship will continue to be relevant in the lives of millions of Africans who are either threatened by the state or else ignored by its agencies. Yet kinship distorts the expansiveness and universalism of civil society. Civil society requires that the worth of the unique individual be recognised beyond his or her ethnic group. However, the ideology of kinship imposes restrictions on the moral worth of individuals, with those from outside its domain being morally valued than the kinsfolk... the universalism of civil society helps to offer common moral empathy, whereas kinship is restrictive in its meaning of freedom. The dilemma of African politics is that the ineptitude of the state emboldens kinship and its organization of ethnic groupings which in turn threatens the operation of civil society appears' (1998).

To advance, these doubts must be counterbalanced with the arguments of the opposing school, which in general is much more convinced of the usefulness of civil society for elucidating African social processes. While those who articulate this position do not doubt the fact of the western provenance of civil society as an idea, they nonetheless argue that an African civil society is not necessarily a contradiction in terms, the relative salience of factors like ethnicity and kinship notwithstanding. According to Michael Bratton, While many pre-colonial cultures in Africa may have lacked states, they certainly did not lack civil societies, in the broad sense of a bevy of institutions for protecting collective interests' (1989:411). One thing is evident here, in making this argument, Bratton, and indeed a majority of scholars of a similar disposition, anchors his reasoning on a particular understanding of civil society, one based on a 'diluted' definition that locates civil society within the mainstream of developments associated with its most recent reincarnation - the struggle for political liberalisation and democratisation of the public sphere. It is in this sense, arguably, that Bratton talks of 'the broad sense of a bevy of institutions for protecting collective interests'.

If that is the case then, civil society is not only useful in describing social dynamics in Africa, it is actually a categorical imperative. Such, it seems, is the range of the analytic vista opened up by this radical interpretation, the basis of which is that civil society is not, as Lars Jorgensen (1996) said, 'the prerogative of European-type industrialised countries' (p.40). According to him, 'In any country, its citizens need to organise to protect their families, develop their agriculture or crafts, form some health service or educational 
initiative, arrange for their burials and so on. The balance to be struck with the other social sectors varies from country to country and period to period' (Ibid). Chabal (1991:93) adds that civil society 'is indispensable to conceptualise politics in Africa'. In addition, Harbeson argues that ' ... civil society by definition roots political values in culturally specific value systems and is thus singularly valuable in overcoming and counteracting ethnocentrism' (1994:27).

These latter contentions suggest radical possibilities for the study and analysis of civil society, and at the very least appear to capture the variety of ways in which civil society is (being) imagined by various political and social communities on the African continent. Are we then at the end of an era; and might one be justified to declare victory for the 'enthusiasts' in this struggle for the hermeneutic futures of an admittedly difficult concept?

This does not seem to be the case. It is obvious for one that its frequent use notwithstanding, the evanescent property of civil society appears to linger. The Comaroffs have aptly spoken of a concept that constantly 'eludes the critical gaze'. At the same time, doubts still persist about its usefulness for explicating African social processes. It is this situation that makes the emergence of the 'alternative genealogy' all the more crucial, especially as it does seem to respond to these nagging doubts in a definitive way. The basic principles of this genealogy are outlined in the following section.

\section{The alternative genealogy of civil society: The issues}

In many cultures and societies as distinct as South Korea, Palestine, and India, civil society is used in some form to express opposition, whether to the elites of a given country or to global capitalist development writ large... For all of these groups, the most common thread is the use of the concept of civil society to legitimise their right to resist the prevailing development paradigm. In so doing they have shown that the liberal meanings of this concept are now truly contested. For some, these liberal meanings have weakened civil society and emptied it of any real content and meaning; for others, civil society has enabled critical voices to occupy an intellectual space where an alternative set of values and propositions on how societies ought to develop and change can be put forward, challenging those that would otherwise dominate (Howell and Pearce 2001:36).

As made clear above, its adoption by several actors and communities in various parts of the world notwithstanding, it has been difficult eradicating the reputation of civil society as a Western import. Thus, expressions of doubt regarding its usefulness appear to have grown in inverse proportion to its popularity and frequency of its use in non-Western contexts. In recent times, these doubts have taken an added urgency given the subtle political ramifications of the use of civil society to demarcate societies that are 'civil' 
from those which are not. The civil/uncivil binary is one of the more fascinating developments in the evolution of recent theoretical reflections on civil society, and partly owes its inspiration to the speculations of Gellner (1994) and Seligman (1992) among others. Specifically, Islamic societies have come under closer scrutiny because they have, in most cases, been cited to illustrate the point about the non-feasibility of civil society in non-Western contexts. To take an example from Gellner, the problem about Islamic societies is that they 'exemplify a social order which seems to lack much capacity to provide political countervailing institutions, which is atomised without much individualism, and operates effectively without intellectual pluralism' (1994:29). Islamic societies are part of the so-called 'segmentary societies' (African societies being another) which, according to Gellner, even though they may boast a surfeit of associations, are nonetheless 'total, many-stranded, underwritten by ritual and made stable through being linked to a whole inside set of relationships' (p.100). Hefner (2000) captures the same argument thus:

That 'Islamic civilization... does not value intermediary institutions between the government and the people, thus precluding the emergence of civil society, and is based on a legal culture of rigidity, thus placing a premium on obedience and social conformity rather than on critical inquiry and individual initiative' (p. vii).

The alternative genealogy of civil society seems partly to have grown out of the desire to respond to these misgivings, and also to provide a description of civil society which, while not totally divorced from its original meaning, at the same time strikes out in newer directions, and takes into cognisance the radical ways in which the notion of civil society has/is being used in different non-Western societies. The challenge for the African continent for example was, as Orvis puts it, 'to create a concept clearly part of the Western tradition, precise enough to have analytical utility, and able to include and reflect the rich associational life of contemporary Africa' (Orvis 2001:20).

What we can refer to as the philosophical bases of the Alternative Genealogy can therefore be summarised as follows: First, that 'in all societies there are values and practices that hover close to the ground and carry latent possibilities, some of which may have egalitarian and democratic possibilities' (Hefner 2000:9). Second, that 'values of mutual support and solidarity exist in the history of human sociability' that for example 'form the basis of a challenge to the predominance of individual accumulation in capitalist development' (Howell and Pearce 2001:36). Third, that civil society has always existed in different forms in other societies. Kamali (1998) for example argues with respect to Islamic societies that civil society was actually there at the very beginning of the establishment of the Islamic political 
order, adding the interesting observation that the first Islamic community was referred to as al-mujtama' al-madani (civil society), 'with civil here indicating the establishment of the city that was composed of Muslim segments allied on tribal and geographic lines, as well as Jews and others who were allied on similar lines' (p. 249). According to him, therefore, 'the term civil society was not exclusively Western, although the definitions and meanings certainly varied. Islamic civil society was based on diversity' (p. 249). Finally, there has also been an attempt to undermine Gellner's submission that 'civil society is a cluster of institutions and associations strong enough to prevent tyranny, but which are, nonetheless, entered and left freely, rather than imposed by birth' (1994:103). Here, Kamali's contention is that, in Iran at least, "civil society... is not directly conditioned by the existence of "sovereign" and "free" individuals, but by groups or communities and their institutions enjoying a significant degree of autonomy from the state' (p. 36).

One immediate fallout of these postulations is that it underlines the need for a definition of civil society that embraces these concerns without sacrificing the original meanings(s) of the concept; in short a definition that is not 'civilizationally circumscribed' (Hefner 2000:221); and one that no longer conveys 'the dilemmas of a small burgeoning class of male merchants and entrepreneurs in one part of the world'. (Howell and Pearce 2001:37). It is apparently with these concerns in mind that civil society has been loosely defined, for example, as 'a social space where individuals and groups can interact and organise social life' (Kamali 1998:xvii).

This is not to presume of course that this definition is acceptable to all concerned, or to deny for that matter the sheer heterogeneity of the groups and tendencies necessarily involved in this project of 're-inventing' civil society. As Hasan Hanafi (2002) has appropriately observed, '...this reinvention of civil society remains theoretically eclectic and confused. While it is possible to detect some of the values, normative ideals, and intellectual currents that influence the new definition, it does not represent a clear body of ideas that can do much more than critique and challenge. Nevertheless, such critique and challenge do make it more difficult for dominant institutions to sustain their claim that their vision of civil society is the natural and only one (pp. 37-38).

I would like to add that these obvious problems notwithstanding, its benefits cannot be ignored. For one, my main argument in this essay is that this project of re-invention seemingly renders redundant the protracted debate about the applicability or otherwise of the concept which has largely dominated the literature on civil society in Africa over the past decade or so. With the focus arguably shifting to a re-definition of civil society as a space 
where groups and individuals can interact and organise social life, and the consequent search for the distinctive elements of the public sphere in various cultural contexts, the concern may have shifted from the applicability or not of the idea to the different ways in which it can be used, among other things, in the cause of social justice.

\section{Possibilities and challenges}

These, then, are the possible futures ${ }^{15}$ with regard to the use and analysis of civil society, with opportunities and challenges alike for both researchers and activists. For the latter, a re-invented notion of civil society, (reflecting as it were 'a multiplicity of diverse and often diverging voices that share a wish to preserve a concern for a common humanity, undo the negative aspects of capitalist development, and promote forms of economic organization that are environmentally sustainable and socially just' (Hanafi 2002:37) becomes a forum through which power can be easily challenged. It is not difficult to imagine how easily this chimes with current social and political concerns everywhere on the continent where the imperative to align power with the interests of the disprivileged remains strong indeed.

Yet this also comes with its own challenges. If activists want equity, so to say, they must come with clean hands. As Farhad Kazemi (2002) has warned, it should be borne in mind by all concerned that '... only a democratic state can create a democratic civil society; only a democratic civil society can sustain a democratic state. The civility that makes democratic politics possible can only be learned in the associational networks; the roughly equal and widely dispersed capabilities that sustain the networks have to be fostered by the democratic state' (p. 319). Adopting civil society within the alternative genealogy framework thus clearly imposes the burden of tolerance and what Kazemi describes as the willingness to accept the fallibility of one's position and that 'there are no right answers'. Before this can be done however, some other things have to be taken into consideration. This brings us to the challenges before scholars. I go back to Howell and Pearce who have entered the caveat 'that civil society does not automatically gain social relevance and meaning as an explanatory or descriptive concept, even though it may in fact adequately describe certain empirical formations. The concept has first to be owned before it can have any political significance' (p. 224).

How is this to be done? One possible way might be to follow the path suggested by Jeffrey Crawford (1998), which is for African scholars to make civil society part of our very own 'intellectual capital'. Historians, political scientists, and anthropologists, I would like to suggest, have several roles to play here. The Western discourse of civil society contains a lot of assumptions about the notion especially in relation to the continent that only further 
systematic investigations by African scholars can help to either reinforce or refute. Part of this, to cite just one example, relates to the relationship between ethnicity, kinship, associationism and civil society, about which, I believe, further empirical investigations can provide greater insight and illumination.

\section{Notes}

1. Earlier versions of this paper were presented at the African Studies Association of the UK (ASAUK) Biennial Conference held at The Manor House, University of Birmingham, 9-11 September 2002, CODESRIA 10th General Assembly 8-12 December 2002, and the PhD Seminar Series at the London School of Economics and Political Science. I owe a particular debt of gratitude to Victor Ayeni, Timothy Shaw, Bjorn Beckman, Hakan Seckinelgin, Wale Adebanwi, and Chris Ankersen for their suggestions and comments.

2. Needless to add of course that this challenge inevitably produced a mixed bag of results across the continent, although it is fair to say that the overwhelming result has been largely salutary.

3. A fine illustration is the Campaign for Democracy (CD) in Nigeria, an umbrella body of numerous fissiparous groups which mobilised against the cancellation of the 1993 presidential election and prolongation of military rule.

4. At the level of ideas, this reveals an interesting possibility - of one having something that one may not be aware of. With regard to Africa, could civil society be one such 'hidden property'?

5. It must be added of course that what seems to be the basic fear among the sceptics centres on the possible danger of 'banalising' civil society once it is removed from its original Western-liberal moorings.

6. This is a direct allusion to Gellner. See my 'Civil Society in Nigeria: Conjectures and Refutations' (Obadare 2002).

7. There are of course several contending narratives on the historical evolution of civil society (see for example Nairn 1997, and Chandhoke 1995), but the one that I describe here is arguably the most dominant, or at least the most popular. As Salvador Giner has observed, 'There is no such thing as the classical conception of civil society. There is a Lockean interpretation, but there is also a Hegelian one; and then there are Hobbesian, Marxian and Gramscian theories of it' (Giner 1995:304).

8. With minor inflections, variations of this evolution can be found in Gellner (1994), Seligman (1992), Cohen and Arato (1992) and Krader (1976) among others.

9. See Gellner (1994:211).

10. Quoted in Comaroff and Comaroff (1999:3). See also Seligman (1992); and for a summary of other issues involved in this debate, see Orvis (2001).

11. It goes without saying that this cannot be achieved in a study of this nature. For studies with a continental focus, see for example Onwudiwe (1998), Monga (1996), Gyimah-Boadi (1997), and Harbeson et al., (1994). 
12. When Michael Kennedy (2001) wrote of 'civil society's polysemous elaboration', he was apparently referring to this difficult conceptual history.

13. For more on this, see Bayart (1986) and Keane (1998).

14. See also Obadare (2004).

15. In their thoughtful and provocative collection of essays, John and Jean Comaroff (1999) also map out possible directions for anthropological studies of civil society in Africa. They emphasise specifically the need for studies that '.. disinter the cultural seedbeds and historical sources of anything that might be regarded as an analogue of civil society in Africa', and for those few that consider 'the sorts of public sphere presumed by specifically African relations of production and exchange, codes of conduct, or styles of social intercourse, by African markets, credit associations, informal economies, collective ritual, modes of aesthetic expression, discourses of magic and reason; by the various strands, in other words, that 'weave the fabric' of the civil here beyond the official purview of governance' (1999:23).

\section{References}

Barber, Benjamin R., 2001, 'Blood Brothers, Consumers, or Citizens? Three Models of Identity- Ethnic, Commercial, and Civic', in Carol C. Gould and Pasquale Pasquino (eds.) Cultural Identity and the Nation State, Lanham: Rowman and Littlefield.

Bayart, Jean-François, 1986, 'Civil Society in Africa' in Patrick chabal, ed., Political Domination in Africa: Reflections on the Limits of Power, Cambridge: Cambridge University Press, pp. 109-125.

Bayart, Jean-Francois, 1993, The State in Africa: The Politics of the Belly, New York: Longman.

Blaney, David L. and Mustapha Kamal Pasha, 1993, 'Civil Society and Democracy in the Third World: Ambiguities and Historical Possibilities', Studies in Comparative International Development, Spring, vol. 28, no. 1, 3-24.

Bratton, Michael, 1989, 'Civil Society and Associational Life in Africa', World Politics, 41 (3): 407-430.

Callaghy, Thomas M., 1994, 'Civil Society, Democracy, and Economic Change in Africa: A Dissenting Opinion About Resurgent Societies', in John Harbeson, Donald Rothchild and Naomi Chazan, (eds.), Civil Society and the State in Africa, London: Lynne Rienner, pp. 231-54.

Cohen, Jean L. and Andrew Arato, 1992, Civil Society and Political Theory, Cambridge: Massachusetts Institute of Technology Press.

Comaroff, John L. and Jean Comaroff, (eds.), 1999, Civil Society and the Political Imagination in Africa Critical Perspectives, Chicago: The University of Chicago Press.

Chabal, Patrick, 1991, Power in Africa: An Essay in Political Interpretation, Basingstoke: Macmillan Academic and Professional. 
Chan, Stephen, 2002, Composing Africa: Civil Society and Its Discontents Tampere Peace Research Institute Occasional Papers Series No. 86, pp. 1-82.

Chandhoke, Neera, 2001, 'A Cautionary Note on Civil Society', Paper presented at the Conference on The Meaning and Value of Civil Society in Different Cultural Contexts, London School of Economics, 28-29 September.

Chandhoke, Neera, 2001, "The "Civil" and the "Political" in Civil Society', Democratization, Vol. 8, No. 2 (Summer), pp.1-24.

Deakin, Nicholas, 2001, In Search of Civil Society, Basingstoke, Palgrave.

Diouf, Mamadou, 1998, Political Liberalisation or Democratic Transition: African Perspectives, Dakar, CODESRIA.

Ekeh, Peter, 1998, 'Civil Society and the Construction of Freedom in African History', Keynote address to Wilberforce Conference on Civil Society in Africa, Central State University, Wilberforce, Ohio.

Ferguson, Adam, 1980, An Essay on the History of Civil Society, With a New Introduction by Louis Schneider, New Brunswick, Transaction Books.

Gellner, Ernest, 1994, Conditions of Liberty: Civil Society and its Rivals, London: Hamish and Hamilton.

Giner, Salvador, 1995, 'Civil Society and its Future', in John A. Hall, (ed.) Civil Society: Theory, History, Comparison, Cambridge: Polity Press.

Gyimah-Boadi, Emmanuel, 1997, 'Civil Society in Africa: the good, the bad the Ugly', Journal: CIVnet's journal for Civil Society, May, vol. 1 no. 1.

Harbeson, John W., 1994, 'Civil Society and Political Renaissance in Africa', in John Harbeson, Donald Rothchild and Naomi Chazan, (eds.), Civil Society and the State in Africa, London: Lynne Rienner, pp. 1-32.

Hefner, Robert W., 2000, Civil Islam Muslims and Democratization in Indonesia, Princeton: Princeton University Press.

Howell, Jude and Jenny Pearce, 2001, Civil Society and Development: A Critical Exploration, London: Lynne Rienner Publishers.

Hutchful, Eboe, 1998, 'The Civil Society Debate in Africa', International Journal 51 (1): 54-77.

Ihonvbere, Julius and Timothy Shaw, 1998, Illusions of Power: Nigeria in Transition, Trenton, New Jersey: Africa World Press.

Jorgensen, Lars, 1996, 'What are NGOs doing in Civil Society?', in Andrew Clayton (ed.), NGOs, Civil Society and the State: Building Democracy in Transitional Societies, Oxford: INTRAC, pp. 36-55.

Kaviraj, Sudipta, and Sunil Khilnani, (eds.), 2001, Civil Society History and Possibilities, Cambridge: Cambridge University Press.

Kamali, Masoud, 1998, Revolutionary Iran: Civil Society and the State in the Modernization Process, Aldershot: Ashgate.

Kazemi, Farhad, 2002, 'Perspectives on Islam and Civil Society', in Rosenblum, Nancy L., and Robert C. Post, Civil Society and Government, Princeton: Princeton University Press, pp. 317-333.

Keane, John, 1998, 'Civil Society: Old Images', New Visions, Cambridge: Polity Press. 
Krader, Lawrence, 1976, 'The Dialectic of Civil Society', Amsterdam: Van Gorcum, Assen.

Lewis, David, 2002, 'Civil Society in African Contexts: Reflections on the Usefulness of a Concept', Development and Change, September, Vol. 33, No. 4, pp. 569-586 (18).

Mamdani, Mahmood, 1995, 'A Critique of the State and Civil Society Paradigm in Africanist Studies', in Mahmood Mamdani and Ernest Wamba-dia-Wamba, (eds.), African Studies in Social Movements and Democracy, Dakar: CODESRIA.

Mamdani, Mahmood, 1997, Citizen and Subject: Contemporary Africa and the Legacy of Late Colonialism, Princeton: N.J: Princeton University Press.

Mardin, Serif, 1995, 'Islam and Civil Society', in John A. Hall, (ed.), Civil Society: Theory, History, Comparison, Cambridge: Polity Press.

Monga, Celestin, 1995, 'Civil Society and Democratisation in Francophone Africa', Journal of Modern African Studies, 33:359-379.

Monga, Celestin, 1996, 'The Anthropology of Anger: Civil Society and Democracy in Africa', Colorado: Lynne Rienner Publishers.

Mustapha, Abdul Raufu, 1998, 'When Will Independence End? Democratization and Civil Society in Rural Africa', in Lars Rudebeck, Olle Tornquist, Virgilio Rojas, (eds.), Democratization in the Third World: Concrete Cases in Comparative and Theoretical Perspective, Basingstoke: Macmillan.

Nairn, Tom, 1997, 'From Civil Society to Civic Nationalism: Evolutions of a Myth', in Tom Nairn, Faces of Nationalism: Janus Revisited, Verso, London.

Nwokedi, Emeka, 1995, Politics of Democratisation Changing Authoritarian Regimes in sub-Saharan Africa, Demokratie und Entwicklung Bd. 18 Munster.

Obadare, Ebenezer, 2002, 'Civil Society in Nigeria: Conjectures and Refutations', in Toyin Falola,(ed.) Nigeria in the Twentieth Century, Durham: CarolinaAcademic Press, pp. 551-60.

Obadare, Ebenezer, 2004, 'The Uses of the Primordial: Reflections on Ethnicity, Civil Society and Democracy in Nigeria' paper accepted for publication in Quarterty Journal of Administration, Obafemi Awolowo University, Ile-Ife, Nigeria, Volume XXXII, No. 1, pp. 124-143.

Onwudiwe, Ebere, ed., 1998, African Perspectives on Civil Society, New York: Tri-Atlantic Books.

Orvis, Stephen, 2001, 'Civil Society in Africa or African Civil Society?', Journal of Asian and African Studies, XXXVII, I, 17-38.

Seligman, Adam B., 1992, The Idea of Civil Society, New York: The Free Press. Tester, Keith, 1992, Civil Society, London and New York: Routledge.

Trentmann, Frank, 1999, Paradoxes of Civil Society: New Perspectives on Modern German and British History, Oxford: Berghahn.

Van Rooy, (ed.), 1998, Civil Society and the Aid Industry, London: Earthscan. Varshney, Ashutosh, 2001, 'Ethnic Conflict and Civil Society in India and Beyond', World Politics, April, pp. 362-98. 